Tropical Journal of Pharmaceutical Research October 2019; 18 (10): 2109-2115

ISSN: $1596-5996$ (print); 1596-9827 (electronic)

(C) Pharmacotherapy Group, Faculty of Pharmacy, University of Benin, Benin City, 300001 Nigeria.

\title{
In vitro antidiabetic, anti-inflammatory and antioxidant potential of the ethanol extract of Uromastyx hardwickii skin
}

\author{
Waqas Ahmad Shams ${ }^{1}$, Gauhar Rehman ${ }^{1}$, Samuel Okwudili Onoja ${ }^{2 \star}$, Abid Ali ${ }^{1}$, \\ Khurshaid Khan', Sadaf Niaz ${ }^{1}$ \\ ${ }^{1}$ Department of Zoology, Abdul Wali Khan University, Mardan, Pakistan, ${ }^{2}$ Department of Veterinary Physiology and \\ Pharmacology, Michael Okpara University of Agriculture, Umudike PMB 7267, Umuahia, Abia State, Nigeria
}

*For correspondence: Email: samonreal@yahoo.com

Sent for review: 19 April 2019

Revised accepted: 17 September 2019

\begin{abstract}
Purpose: To evaluate the in vitro antidiabetic, anti-inflammatory and antioxidant potential of the ethanol extract of Uromastyx hardwickii Skin (UHSEE).

Methods: The in vitro effects of UHSEE at various concentrations (10 - 250 $\mu \mathrm{g} / \mathrm{mL})$ on the activities of $\alpha$-amylase, $\alpha$-glucosidase and glucose uptake by yeast cells were used to evaluate its antidiabetic potential. Nitric oxide (NO), 2,2-diphenyl-1-picrylhydrazyl (DPPH) and hydrogen peroxide inhibitory assay were employed to determine its antioxidant effects, while the anti-inflammatory effects were evaluated using human red blood cell (HRBC) membrane stabilization assay.

Results: UHSEE inhibited $\alpha$-amylase and $\alpha$-glucosidase enzymes but increased glucose uptake by yeast cells in a concentration-dependent manner $(p<0.05)$. It also inhibited NO, DPPH, hydrogen peroxide and HRBC hemolysis in a concentration-dependent manner $(p<0.05)$.

Conclusion: Uromastyx hardwickii skin exhibits promising good antidiabetic, antioxidant and antiinflammatory properties in vitro. However, its true potentials in this regard needs to be evaluted in vivo.
\end{abstract}

Keywords: Uromastyx hardwickii skin, Antidiabetic, Antioxidant, Anti-inflammatory, 2,2-Diphenyl-1picrylhydrazyl, Membrane stabilization

\begin{abstract}
This is an Open Access article that uses a fund-ing model which does not charge readers or their institutions for access and distributed under the terms of the Creative Commons Attribution License (http://creativecommons.org/licenses/by/4.0) and the Budapest Open Access Initiative (http://www.budapestopenaccessinitiative.org/read), which permit unrestricted use, distribution, and reproduction in any medium, provided the original work is properly credited.
\end{abstract}

Tropical Journal of Pharmaceutical Research is indexed by Science Citation Index (SciSearch), Scopus, International Pharmaceutical Abstract, Chemical Abstracts, Embase, Index Copernicus, EBSCO, African Index Medicus, JournalSeek, Journal Citation Reports/Science Edition, Directory of Open Access Journals (DOAJ), African Journal Online, Bioline International, Open-J-Gate and Pharmacy Abstracts

\section{INTRODUCTION}

Diabetes mellitus is a chronic metabolic and hormonal disorder characterized by hyperglycemia due to reduced insulin release or insulin resistance [1]. Effective management of hyperglycemia, especially postprandial hyperglycemia in diabetic patients has been a major challenge in the clinical treatment of diabetes mellitus. Postprandial hyperglycemia is regulated by $\alpha$-glucosidase and $\alpha$-amylase, which catalyze the digestion of carbohydrate in the gut [2]. The down-regulation of $\alpha$-glucosidase and $\alpha$-amylase reduces the rate of glucose digestion and absorption, which ultimately diminishes the magnitude of postprandial hyperglycemia in both hyperglycemic and normoglycemic patients [3]. 
Hyperglycemia is associated with non-enzymatic glycation of protein molecules that lead to elevated production and release of reactive oxygen species (ROS) [4]. The ROS are implicated in the pathogenesis of diabetes mellitus and its complications as well as other disease conditions. They elicit release of inflammatory mediators, predisposes to insulin resistance and cardiovascular diseases. Diabetes has been described as a chronic inflammatory condition [5,6]. Owing to the above fact, the roles of anti-inflammatory agents and antioxidants in treating diabetes should not be under-estimated. The anti-inflammatory properties of common hypoglycemic drugs used in the clinical treatment of diabetes have been reviewed [6]. Their effects are not just via the reduction of plasma glucose level but also through the modulation of potent inflammatory mediators $[6,7]$.

The use of natural products of either plant or animal origin in the traditional management of diabetes and other disease conditions is popular among Asians and Africans [8,9]. This is due to the high cost and unavailability of orthodox medicines as well as the perceived low sideeffects, cultural acceptance and availability of traditional medicines $[10,11]$. One of the commonly used animal products in the ethnomedical treatment of diabetes in Pakistan is the skin of Uromastyx hardwickii [12].

Uromastyx hardwickii, popularly known as Hardwicke's spiny-tailed lizard or the Indian spiny-tailed lizard is a species of lizard belonging to the family Agamidae. It is a desert lizard found in both rocky and sandy environs of North Africa and the Middle East, especially India and Pakistan [13]. It is called "Barti chpkali" in Pakistan and the skin is used in the ethnomedical treatment of diabetes mellitus [12].

There is dearth of scientific evidence of its antidiabetic potential, hence this study evaluates the in vitro antidiabetic, antioxidant and antiinflammatory properties of the ethanol extract of Uromastyx hardwickii skin.

\section{EXPERIMENTAL}

\section{Collection of Uromastyx hardwickii}

Four of Uromastyx hardwickii lizards were collected from desert and semi-desert areas of Pakistan. They were identified and the specimens were kept in the museum at Department of Zoology, Abdul Wali Khan University, Mardan khyber Puktunkhwa Pakistan. The lizards were handled according to the Guide for the Use and Care of Laboratory Animals of National Research Council [14].

The experimental protocols was approved by the Ethics and Animal Care Committee, of Department of Zoology, Abdul Wali Khan University, Mardan khyber Puktunkhwa Pakistan (No: AWKUM/ZOO/2018/1770).

\section{Preparation of the extract of Uromastyx hardwickii skin}

Uromastyx Hardwickii were anesthetized with diethyl ether and then sacrificed. The skins were excised as described by Brito-Casillas et al [15]. They were dried under shade and ground into powder. About $200 \mathrm{~g}$ of the powdered sample was extracted with ethanol using Soxhlet apparatus for $8 \mathrm{~h}$. The ethanol extract of Uromastyx hardwickii skin (UHSEE) was concentrated in vacuo using rotary evaporator at $40{ }^{\circ} \mathrm{C}$.

\section{Evaluation of in vitro antidiabetic}

\section{a-Glucosidase inhibitory activity}

The a-glucosidase inhibitory activities of UHSEE and acarbose (10 - $250 \mu \mathrm{g} / \mathrm{mL}$ concentration) were determined as described by Mopuri et al [16] without modification. The acarbose was used as the reference standard and the results were expressed as percentage inhibition of $\alpha$ glucosidase activities. Same volume $(0.25 \mathrm{~mL})$ of different concentrations $(10-250 \mu \mathrm{g} / \mathrm{mL}$ ) of UHSEE or acarbose were incubated with 0.50 $\mathrm{mL}$ a-glucosidase solution $(1.0 \mathrm{U} / \mathrm{mL}$ in $0.1 \mathrm{M}$ phosphate buffer of $\mathrm{pH} \mathrm{6.8)}$ at $37^{\circ} \mathrm{C}$ for $15 \mathrm{~min}$. Later, $0.25 \mathrm{~mL}$ of 4-nitrophenyl $\beta$-Dglucopyranoside (pNPG) solution $(5 \mathrm{mM}$ in $0.1 \mathrm{M}$ phosphate buffer of $\mathrm{pH}$ 6.8) was added and further incubated at $37{ }^{\circ} \mathrm{C}$ for $20 \mathrm{~min}$. The absorbance of the mixture was measured spectrometrically at $405 \mathrm{~nm}$ and the inhibitory activity was expressed in percentage.

\section{Determination of a-amylase inhibitory activity}

The inhibitory activity of various concentrations $(10-250 \mu \mathrm{g} / \mathrm{mL}$ ) of UHSEE on $\alpha$-amylase was measured using a spectrophotometer [17]. A known volume $(0.25 \mathrm{~mL})$ of different concentrations of UHSEE and miglitol were incubated with $0.50 \mathrm{~mL}$ of porcine pancreatic amylase $(2 \mathrm{U} / \mathrm{mL}$ in $0.10 \mathrm{M}$ phosphate buffer of $\mathrm{pH}$ 6.8) solution at $37^{\circ} \mathrm{C}$ for $20 \mathrm{~min}$. Later, 0.25 $\mathrm{mL}$ of starch $(10 \mathrm{mg} / \mathrm{mL}$ in $0.10 \mathrm{M}$ phosphate buffer of $\mathrm{pH}$ 6.8) was added to the mixture, which was incubated at $37{ }^{\circ} \mathrm{C}$ for $60 \mathrm{~min}$. $1 \mathrm{~mL}$ of dinitrosalicylate colour reagent was added and 
boiled for $10 \mathrm{~min}$. The absorbance was determined at $540 \mathrm{~nm}$. The results were presented as percentage inhibition of a-amylase activities and miglitol was used as reference standard. The percentage inhibition of $\alpha$ glucosidase and $\alpha$-amylase activities were calculated using Eq 1.

$$
\text { Inhibition }(\%)=\frac{X A-Y A}{X A} \times \frac{100}{v} \text {. }
$$

where $\mathrm{XA}=$ absorbance of control, $\mathrm{YA}=$ absorbance of test substance

\section{Effect of UHSEE on glucose uptake by yeast cells}

The effects of UHSEE and metformin $(10-250$ $\mu \mathrm{g} / \mathrm{mL}$ ) on glucose uptake by yeast cells (Saccharomyces cerevisiae) (Malteserkors, Denmark) were evaluated as described by Bhutkar and Bhise [18]. The yeast cells were washed by repeated centrifugation (4200 rpm, 5 min) in distilled water until the supernatant fluid were clear. $10 \%(\mathrm{v} / \mathrm{v})$ suspension of yeast was prepared in distilled water. $1 \mathrm{~mL}$ of glucose solution (25 $\mathrm{mmol} / \mathrm{L})$ was added to varied concentrations $(10-250 \mu \mathrm{g} / \mathrm{mL})$ of UHSEE and the mixture was incubated at $37^{\circ} \mathrm{C}$ for $10 \mathrm{~min}$.

After $10 \mathrm{~min}, 0.1 \mathrm{~mL}$ of the yeast suspension was added to the mixture, which was incubated (after thorough mixing) at $37^{\circ} \mathrm{C}$ for $60 \mathrm{~min}$. Later, the tubes containing the mixture were spun at 3800 rpm for $5 \mathrm{~min}$ in a centrifuge and the glucose concentration in the supernatant was determined. Each concentration was determined in triplicate and metformin was used as reference standard. The result is expressed as increase in glucose uptake (G) s shown in Eq 2 [18].

$\mathrm{G}(\%)=\frac{x-Y}{x} \times \frac{100}{1}$

where $\mathrm{X}=$ absorbance of control, $\mathrm{Y}=$ absorbance of test substance

\section{Evaluation of antioxidant activity}

\section{Nitric oxide (NO) radical scavenging assay}

The NO radical scavenging assay of UHSEE was performed by monitoring the intensity of chromophore formed by reacting Griess reagent and nitrite liberated from sodium nitroprusside. Varied concentrations (10 - $250 \mu \mathrm{g} / \mathrm{mL})$ of UHSEE were tested in triplicate as described by Bryan and Grisham [19]. The results are expressed as inhibition $(\mathrm{H})$. Gallic acid was used as standard.

\section{DPPH radical scavenging assay}

The abilities of UHSEE to electron donation was evaluated with $1 \mathrm{mM}$ solution of 2,2-diphenyl-1picrylhydrazyl (DPPH) in ethanol as described by Ak and Gulcin [20]. This protocol estimated the DPPH radical scavenging potential of UHSEE at various concentrations $(10-250 \mu \mathrm{g} / \mathrm{mL})$. The bleaching of the purple colour of DPPH solution to yellow was monitored spectrophotometrically at $517 \mathrm{~nm}$ after $30 \mathrm{~min}$ incubation in the dark at room temperature. Ascorbic acid was used as reference and the result was expressed as percentage free radical scavenging of DPPH.

$\mathrm{H}(\%)=\frac{A O-A I}{A 0} \times \frac{100}{1}$

where $\mathrm{AO}=$ absorbance of control; $\mathrm{Ai}=$ absorbance of test substance

\section{Hydrogen peroxide scavenging assay}

The ability of UHSEE to decompose hydrogen peroxide $\left(\mathrm{H}_{2} \mathrm{O}_{2}\right)$ into water and oxygen gas was determined as described by Oktay et al [21] without modification. About $2.4 \mathrm{~mL}$ varied concentrations $(10-250 \mu \mathrm{g} / \mathrm{mL})$ of UHSEE were incubated with $0.6 \mathrm{~mL} \mathrm{H}_{2} \mathrm{O}_{2}(2 \mathrm{mmol} / \mathrm{L}$, in phosphate buffer of $\mathrm{pH} 7.4$ ) for $10 \mathrm{~min}$. The concentration of $\mathrm{H}_{2} \mathrm{O}_{2}$ was estimated spectrophotometrically at $230 \mathrm{~nm}$ and molar absorptive coefficient of $81 \mathrm{~mol} / \mathrm{L}^{-1} / \mathrm{cm}$. Ascorbic acid was used as standard and the results are expressed as inhibition.

$\mathrm{H}(\%)=\frac{X 0-X i}{X_{0}} \times \frac{100}{1}$

where $\mathrm{Xo}_{\mathrm{O}}=$ absorbance of control, $\mathrm{Xi}=$ absorbance of test substance

\section{Determination of anti-inflammatory activity}

\section{Human red blood cell (HRBC) membrane stabilization assay}

The effects of UHSEE on the hemolysis of human red blood cell (HRBC) in hypotonic saline solution was evaluated as described by Anosike et al [22]. Blood sample (5 ml) was collected from a healthy male donor (that has not received antiinflammatory drug in the past 10 days) into EDTA sample bottle. The HRBC was repeatedly washed with normal saline by centrifugation as described by Anosike et al [22] until the supernatant was clear. Thereafter, $0.5 \mathrm{~mL}$ of 10 $\%$ suspension of the HRBC was added to test tubes containing different concentrations (5 $250 \mu \mathrm{g} / \mathrm{mL}$ ) of UHSEE dissolved in hypotonic saline solution in triplicate. The mixtures were 
incubated for $30 \mathrm{~min}$ at $37{ }^{\circ} \mathrm{C}$ and later centrifuged at $3000 \mathrm{rpm}$ for $5 \mathrm{~min}$. The absorbance of the supernatants was recorded at $560 \mathrm{~nm}$ with spectrophotometer. Hypotonic solution was used as control while diclofenac $(250 \mu \mathrm{g} / \mathrm{mL})$ was used as reference standard. Inhibition $(\mathrm{H})$ was calculated as in Eq 5.

$\mathrm{H}(\%)=\frac{A A-B D}{A A} \times \frac{100}{1}$

where $\mathrm{AA}=$ absorbance of control, $\mathrm{BB}=$ absorbance of test substance

\section{Heat-induced hemolysis assay}

The effects of UHSEE on heat-induced hemolysis of HRBC was evaluated as described by Anosike et al [22]. The blood collection and preparation were as stated in the previous section. Thereafter $0.5 \mathrm{ml}$ of $10 \%$ suspension of the HRBC was added to test tubes containing different concentrations $(5-250 \mu \mathrm{g} / \mathrm{mL})$ of UHSEE dissolved in saline in triplicate. The mixtures were incubated for $30 \mathrm{~min}$ at $54^{\circ} \mathrm{C}$ and later centrifuged at $3000 \mathrm{rpm}$ for $5 \mathrm{~min}$. The absorbance (ABS) of the supernatants was determined at $560 \mathrm{~nm}$ with spectrophotometer. Hypotonic solution was used as control while diclofenac $(250 \mu \mathrm{g} / \mathrm{mL})$ was used as reference standard. Inhibition $(\mathrm{H})$ was computed as in Eq 6 .

$H(\%)=\frac{N 0-K u}{N o} \times \frac{100}{1}$

where $\mathrm{Ko}=$ absorbance of control, $\mathrm{Ku}=$ absorbance of test.

\section{Statistical analysis}

Data were subjected to ANOVA followed by Tukey's multiple comparison test to determine significant difference using SPSS 22.0 software. $P<0.05$ was considered sttisticlly significant.

\section{RESULTS}

\section{Effect of UHSEE on $\alpha$-glucosidase activity}

The UHSEE and acarbose produced concentration-dependent inhibition of $\alpha$ glucosidase activities (Figure 1). The $\alpha$ glucosidase inhibitory activity of UHSEE was significantly $(p<0.05)$ lower compared to that of acarbose.

\section{Effect of UHSEE on $\alpha$-amylase activity}

UHSEE and miglitol inhibited $\alpha$-amylase activity in a concentration-dependent manner (Figure 2). The inhibitory effects of UHSEE and miglitol against $\alpha$-amylase activities were comparable except at 200 and $250 \mu \mathrm{g} / \mathrm{mL}$ where the former produced lower effects.

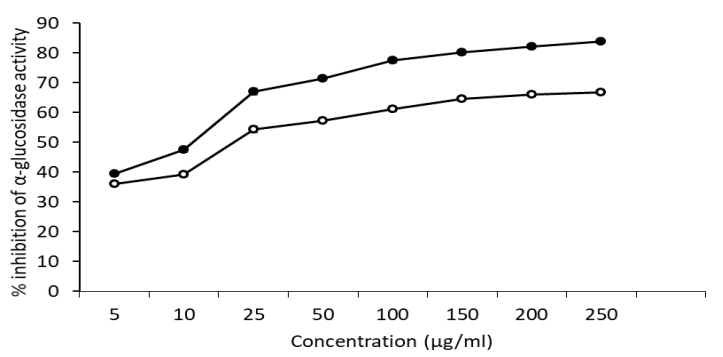

Figure 1: Effect of UHSEE on a-glucosidase activity. Key: -०-, UHSEE; -•-, Acarbose

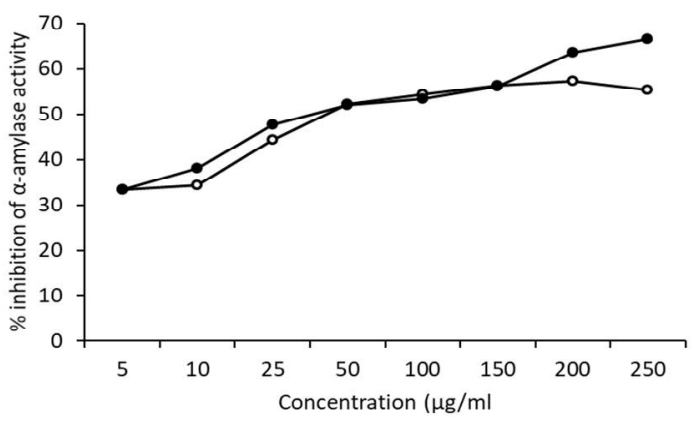

Figure 2: Inhibitory effect of UHSEE against $\alpha$ amylase activities. Key: -०-, UHSEE; -•-, miglitol

\section{Effect of UHSEE on glucose uptake by yeast cells}

The UHSEE and standard inhibited glucose uptake by yeast cells in a concentrationdependent manner (Figure 3). The inhibitory effects of UHSEE and metformin were comparable.

\section{Nitric oxide (NO) scavenging activity}

Both UHSEE and gallic acid inhibited nitric oxide (NO) in a concentration-dependent manner. Their inhibitory properties against NO were comparable (Figure 4).

\section{DPPH radical scavenging activity}

The UHSEE and ascorbic acid produced concentration-dependent increase in the scavenging of DPPH radicals (Figure 5).

\section{Hydrogen peroxide scavenging}

UHSEE and ascorbic acid scavenged hydrogen peroxide in a concentration-dependent manner (Figure 6). The hydrogen peroxide scavenging ability of UHSEE was lower $(p<0.05)$ compared to ascorbic acid. 


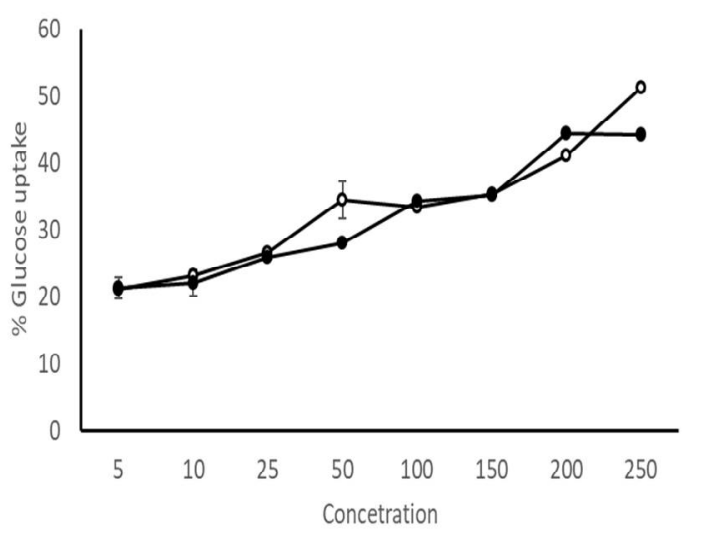

Figure 3: Effect of UHSEE on the uptake of glucose by yeast cells. Values are mean $\pm S D$ of triplicate determinations. Key: -०-, UHSEE; -•-, Ascorbic acid

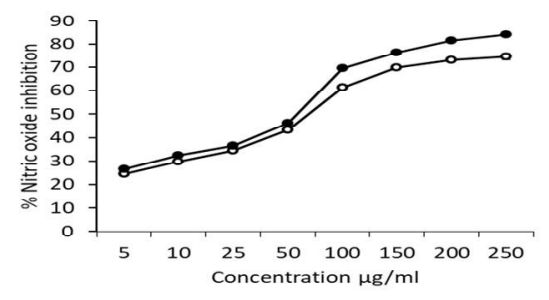

Figure 4: Inhibitory effect of UHSEE on nitric oxide (NO). Key:-०-, UHSEE; -•-, gallic acid

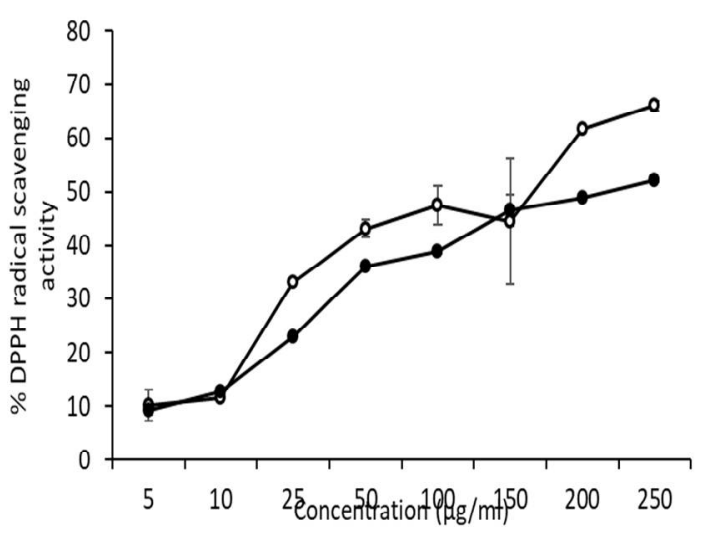

Figure 5: DPPH radical scavenging effect of UHSEE. Key: -०-, UHSEE; -•-, Ascorbic acid

\section{Effect of UHSEE on HRBC-membrane stability}

The USHEE inhibited HRBC hemolysis in a concentration-dependent manner. The antihaemolytic activities of UHSEE at $150-250$ $\mu \mathrm{g} / \mathrm{mL}$ were comparable to diclofenac at 250 $\mu \mathrm{g} / \mathrm{mL}$ (Table 1).

\section{Effect of UHSEE on heat-induced haemolysis}

UHSEE inhibited heat-induced hemolysis of HRBC in a concentration-dependent manner (Table 2).

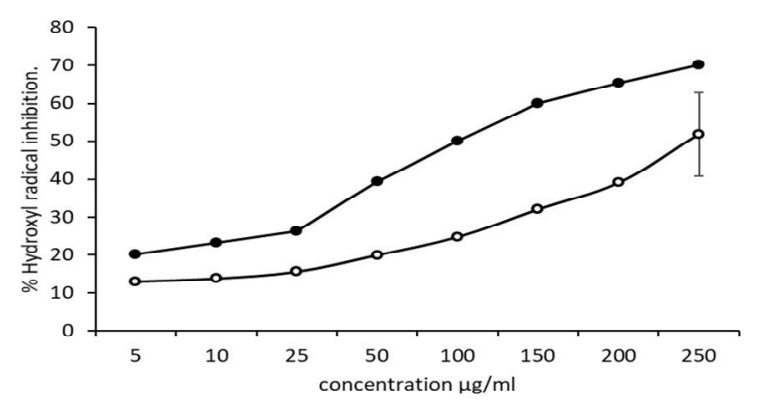

Figure 6: Hydrogen peroxide scavenging activity of UHSEE. Key: -०-, UHSEE; -•-, Ascorbic acid

Table 1: Effect of UHSEE on HRBC- membrane stabilization

\begin{tabular}{lcc}
\hline Treatment & $\begin{array}{c}\text { Concentration } \\
(\boldsymbol{\mu g} / \mathbf{m L})\end{array}$ & Inhibition (\%) \\
\hline Extract & 5 & $11.76 \pm 0.10$ \\
& 10 & $24.89 \pm 0.16$ \\
& 25 & $29.67 \pm 0.21$ \\
& 50 & $45.78 \pm 0.14$ \\
& 100 & $54.37 \pm 0.14$ \\
& 150 & $61.49 \pm 0.14$ \\
& 200 & $68.92 \pm 0.14$ \\
Diclofenac & 250 & $71.32 \pm 0.14$ \\
\hline Data are expressed as mean $\pm \mathrm{SD}(\mathrm{n}=3)$
\end{tabular}

Table 2: Effect of UHSEE on heat induced haemolysis

\begin{tabular}{lcc}
\hline Treatment & $\begin{array}{c}\text { Concentration } \\
(\boldsymbol{\mu g} / \mathbf{m L})\end{array}$ & $\begin{array}{c}\text { Inhibition } \\
(\%)\end{array}$ \\
\hline Extract & 5 & $23.45 \pm 0.65$ \\
& 10 & $25.55 \pm 0.25$ \\
& 25 & $35.08 \pm 0.20$ \\
& 50 & $38.55 \pm 0.30$ \\
& 100 & $43.74 \pm 0.16$ \\
& 150 & $49.78 \pm 0.85$ \\
& 200 & $61.90 \pm 0.90$ \\
& 250 & $72.67 \pm 1.64$ \\
Diclofenac & 250 & $65.86 \pm 0.30$ \\
\hline Data are expressed as mean \pm SD $(\mathrm{n}=3)$
\end{tabular}

\section{DISCUSSION}

The ethanol extract of Uromastyx hardwickii skin (UHSEE) inhibited the activities of $\alpha$-glucosidase and $\alpha$-amylase and increased glucose uptake by yeast cells in a concentration-dependent manner. UHSEE also scavenged reactive oxygen, hydroxyl and NO radicals as well as inhibited the haemolysis of HRBC induced by heat and hypotonic saline.

The inhibition of $\alpha$-glucosidase and $\alpha$-amylase activities by UHSEE suggests that it has the capacity to delay carbohydrate digestion and glucose absorption, which will significantly reduce the postprandial increase in blood glucose. The regulation of postprandial hyperglycemia in diabetic patients is severely impaired due to compromised insulin secretion or 
insulin resistance [23]. Agents such as acarbose and miglitol which inhibit $\alpha$-glucosidase and $\alpha$ amylase activities are useful in the management of type 2 diabetes mellitus [24]. The results of this study are in agreement with the report of Gopal et al [25] on the antidiabetic activities of Lactuca sativa.

The UHSEE enhanced glucose uptake by yeast cells indicates that it might promote glucose uptake by peripheral cells [18]. Increase in the uptake of glucose by skeletal and hepatic cells is the mechanism of action of metformin. This indicates that UHSEE and metformin may possess similar mechanisms of action.

The inhibitory activity of UHSEE on reactive oxygen species and NO radicals imply that it has antioxidant property that can alleviate oxidative stress implicated in the development and progression of diabetes mellitus and its complications [4]. The finding of this study is in agreement with the report of Da Cunha et al [26] on the antioxidant and antidiabetic potentials of Apis mellifera.

Membrane stabilization test was used to evaluate the anti-inflammatory potential of UHSEE. It significantly inhibited the haemolysis of HRBC in concentration-dependent manner, in both hypotonic saline and under heat stress. This suggests that UHSEE possesses antiinflammatory properties. UHSEE may have stabilized the membrane of HRBC by inhibiting the rupture and release of lysosomal enzymes [22], which normally accompanies the inflammatory process. The anti-inflammatory activity of UHSEE observed in the present study corroborates the earlier work of Ferreirra et al [27] on zoo therapeutics used in Brazillian traditional medicine. The anti-inflammatory property of UHSEE could be useful in the treatment of diabetes, which is essentially an inflammatory process.

\section{CONCLUSION}

The ethanol extract of Uromastyx hardwickii skin (UHSEE) possesses good antidiabetic, antioxidant and anti-inflammatory properties in vitro. The findings lend some support for the use of UHSEE for treating diabetes in traditional medicine in Pakistan.

\section{DECLARATIONS}

\section{Acknowledgement}

The authors are grateful to the technical staff of
Department of Zoology, Abdul Wali Khan University, Mardan Pakistan for their assistance.

\section{Conflict of interest}

No conflict of interest is associated with this work.

\section{Contribution of authors}

We declare that this work was done by the authors named in this article and all liabilities pertaining to claims relating to the content of this article will be borne by the authors.

\section{Open Access}

This is an Open Access article that uses a funding model which does not charge readers or their institutions for access and distributed under the terms of the Creative Commons Attribution License (http://creativecommons.org/licenses/by/ 4.0) and the Budapest Open Access Initiative (http://www.budapestopenaccessinitiative.org/rea d), which permit unrestricted use, distribution, and reproduction in any medium, provided the original work is properly credited.

\section{REFERENCES}

1. Olokoba $A B$, Obateru OA, Olokoba LB. Type 2 diabetes mellitus: $A$ review of current trends. Oman Med J 2012; 27(4): 269-273.

2. Li K, Yao F, Du J, Deng X, Li C. Persimmon tannin decreased the glycemic response through decreasing the digestibility of starch and inhibiting $\alpha$-amylase, $\alpha$ glucosidase, and intestinal glucose uptake. J Agric Food Chem 2018; 66(7): 1629-1637.

3. Vadivelan $R$, Krishnan RG, Kannan $R$. Antidiabetic potential of Asparagus racemosus Willd leaf extracts through inhibition of $\alpha$-amylase and $\alpha$-glucosidase. $J$ Tradit Complement Med 2019; 9(1): 1-4.

4. Ishibashi $Y$, Matsui $T$, Maeda $S$, Higashimoto $Y$, Yamagishi S. Advanced glycation end products evoke endothelial cell damage by stimulating soluble dipeptidyl peptidase-4 production and its interaction with mannose 6-phosphate/insulin-like growth factor II receptor. Cardiovasc Diabetol 2013; 2: 125. doi:10.1186/14752840-12-125

5. Esser N, Legrand-Poels S, Piette J, Scheen AJ, Paquot $N$. Inflammation as a link between obesity, metabolic syndrome and type 2 diabetes. Diabetes Res Clin Pract 2014; 105: 141-150.

6. Scheen AJ, Esser N, Paquot N. Antidiabetic agents: potential anti-inflammatory activity beyond glucose control. Diabetes Metab 2015; 41(3): 183-194. 
7. Hyun E, Ramachandran R, Hollenberg MD, Vergnolle N. Mechanisms behind the anti-inflammatory actions of insulin. Crit Rev Immunol 2011; 31: 307-340

8. Mahomoodally MF, Mootoosamy A, Wambugu S. Traditional therapies used to manage diabetes and related complications in Mauritius: A comparative ethnoreligious study. Evid Based Complement Alternat Med 2016, Article ID 4523828, https://doi.org/ 10.1155/2016/4523828.

9. Odeyemi S, Bradley G. Medicinal plants used for the traditional management of diabetes in the Eastern Cape, South Africa: pharmacology and toxicology. Molecul 2018; 23(11): 2759. https://doi.org/10.3390/molecules 23112759

10. Busari AA, Mufutau MA. High prevalence of complementary and alternative medicine use among patients with sickle cell disease in a tertiary hospital in Lagos, South West, Nigeria. BMC Complement Altern Med 2017; 17(1): 299. https://doi.org/10.1186/s12906017-1812-2

11. Suganya $M$, Vikneshan $M$, Swathy $U$. Usage of complementary and alternative medicine: a survey among Indian dental professionals. Complement Ther Clin Pract 2017; 26: 26-29.

12. Shams WA, Rehman G, Ullah Z, Ara S, Niaz S, Ali A, Khan K, Alam H, Gul N, Naz T, ul Islam S. 24. Zootherapeutic practices in Swabi district of Khyber Pakhtunkhawa Pakistan. Pure Appl Biol 2019; 8(1): 222 231.

13. Evans S. "Uromastyx hardwickii" (On-line), Digital Morphology. 2003. Accessed April 10, 2019 at http://digimorph.org/speciens/Uromastyx_hardwickii/.

14. National Research Council. Guide for the care and use of laboratory animals. National Academies Press; 2010.

15. Brito-Casillas Y, López-Ríos L, Wiebe JC, MuñozMediavilla C, Nóvoa-Mogollón FJ, Ojeda A2, Wägner $A M$. Uromastyx acanthinura as a natural treatment in a mouse model of type 2 diabetes. Endocrinol Nutr 2016; 63(1): 13-18.

16. Mopuri R, Ganjayi M, Meriga B, Koorbanally NA, Islam MS. The effects of Ficus carica on the activity of enzymes related to metabolic syndrome. J Food Drug Anal 2018; 26(1): 201-210.

17. Shai LJ, Masoko P, Mokgotho MP, Magano SR, Mogale $A M$, Boaduo N, Eloff JN. Yeast alpha glucosidase inhibitory and antioxidant activities of six medicinal plants collected in Phalaborwa, South Africa. South Afr J Bot 2010; 76: 465-470

18. Bhutkar M, Bhise S. In vitro hypoglycemic effects of Albizzia lebbeck and Mucuna pruriens. Asian Pac J Trop Biomed 2013; 3(11): 866-870.

19. Bryan NS, Grisham MB. Methods to detect nitric oxide and its metabolites in biological samples. Free Radic Biol Med. 2007; 43(5): 645-657.

20. Ak T, Gülçin i. Antioxidant and radical scavenging properties of curcumin. Chem Biol Interact 2008; 174(1): 27-37.

21. Oktay M, Gülçin I, Küfrevioğlu Öl. Determination of in vitro antioxidant activity of fennel (Foeniculum vulgare) seed extracts. LWT-Food Sci Technol 2003; 36(2): 263271.

22. Anosike CA, Obidoa O, Ezeanyika LU. Membrane stabilization as a mechanism of the anti-inflammatory activity of methanol extract of garden egg (Solanum aethiopicum). DARU J Pharm Sci 2012; 20(1): 76. doi: 10.1186/2008-2231-20-76.

23. Frandsen CS, Dejgaard TF, Madsbad S. Non-insulin drugs to treat hyperglycaemia in type 1 diabetes mellitus. Lancet Diabetes Endocrinol 2016; 4(9): 766780.

24. Figueiredo-González M, Grosso C, Valentão $P$, Andrade $P B$. $\alpha$-Glucosidase and $\alpha$-amylase inhibitors from Myrcia spp.: a stronger alternative to acarbose? J Pharm Biomed Anal 2016; 118: 322-327.

25. Gopal SS, Lakshmi MJ, Sharavana G, Sathaiah G, Sreerama YN, Baskaran V. Lactucaxanthin-a potential anti-diabetic carotenoid from lettuce (Lactuca sativa) inhibits $\alpha$-amylase and $\alpha$-glucosidase activity in vitro and in diabetic rats. Food Funct 2017; 8(3): 1124-1131

26. Da Cunha JD, Alfredo TM, dos Santos JM, Junior VV, Rabelo LA, Lima ES, de Araujo Boleti AP, Carollo CA, dos Santos EL, de Picoli Souza K. Antioxidant, antihyperglycemic, and antidiabetic activity of Apis mellifera bee tea. PloS one 2018; 13(6): e0197071.

27. Ferreira FS, Brito SV, Sales DL, Menezes IR, Coutinho $H D$, Souza EP, Almeida WO, Alves RR. Antiinflammatory potential of zootherapeutics derived from animals used in Brazilian traditional medicine. Pharm Biol 2014; 52(11): 1403-1410. 